\title{
Assessing the Chronic Poisoning of White Mice Affected by Mospilan RP and Actara 25 WG
}

\author{
Volodymyr Dukhnytskyi ${ }^{1}$, Vasyl Sokolyuk ${ }^{2}$, Nataliia Kozii ${ }^{3 *}$, Irina Ligomina ${ }^{2}$, Vasyl Karpyuk ${ }^{2}$, and Volodymyr \\ Honcharenko ${ }^{2}$
}

${ }^{1}$ National University of Life and Environmental Sciences of Ukraine, Heroyiv Oboronyst., 15, Kyiv, 03041, Ukraine

${ }^{2}$ Polissya National University, Zhytomyr, Staryi Blvd., 7, Zhytomyr, 10008, Ukraine

${ }^{3}$ Bila Tserkva National Agrarian University, Sq. Soborna, 8/1, Bila Tserkva, Kyiv region, 09100, Ukraine

*Corresponding author's Email: nataliia.kozii@btsau.edu.ua; (D)RCiD: 0000-0002-0141-4390

\begin{abstract}
Neonicotinoids are a relatively small group of organic compounds that are widely used in crop production as insecticides. They are highly toxic to insects, and much less toxic to mammals, including humans. Accordingly, the present study aimed to investigate the effects of chronic toxicity of insecticides from the group of neonicotinoids Mospilan RP (active substance acetamiprid) and Actara 25 WG (active substance thiamethoxam) on white mice. The chronic toxicity was induced by daily internal introduction of Mospilan RP and Actara 25 WG to mice for 30 days at the doses of 1/10 of Median Lethal Dose reported as 65 and $363 \mathrm{mg} / \mathrm{kg}$ of body weight, respectively. The affected mice showed thrombocytosis, neutrophilic leukocytosis, and lymphocytopenia. Blood plasma hyperproteinemia in mice treated with Mospilan RP and Actara 25 WG was characterized by an increase in globulins content by almost $30.0 \%$ in both groups. In Mospilan RP and Actara 25 WG treated groups, there was a reduction in urea content by $43.6 \%$ and $31.5 \%$, respectively, an increase in aspartate aminotransferase activity by $80 \%$ and $60.0 \%$, and $\gamma$ glutamyltranspeptidase by $80 \%$ and almost $400 \%$, respectively. Compared to the control group, the activity of alanine aminotransferase increased to $23.0 \%$ only in mice that were given Mospilan RP but not in mice that were given Actara 25 WG.
\end{abstract}

Keywords: Actara 25 WG, Chronic Toxicity, Insecticides Toxicity, Mospilan PP, Neonicotinoids, White Mice

\section{INTRODUCTION}

The latest agricultural technologies require the extensive use of pesticides and agrochemicals. There is an annual growth of pesticide usage in Ukraine and the world. For instance, 15 years ago, the prevalence of pesticide usage in Ukraine mounted to more than 300 active substances with about 400 preparative forms (Kovalenko et al., 2010).

The use of pesticides and agrochemicals in agriculture is a necessary condition for obtaining a high yield. Scientific research and practical experience have proven that one of the most effective methods of protecting plants from diseases and pests is the use of chemicals. There has been a growing concern regarding the negative effects of pesticides on animal and human health (Christen et al., 2017; Wood et al., 2018; Wood et al., 2019). Concurrently, the agricultural pests develop a certain level of insensitivity to the chemicals. The adaptation of pests to pesticides develops over 10-30 generations and it supports the validity of evolution theory, meaning that in the process of microevolution, a new property is produced (Lavryshyn et al., 2016). For instance, the Colorado potato beetle has developed immunity to insecticides. Being aware of this, the farmers may increase the concentration of insecticides used on fields up to 10 times over recommended dosages which is harmful to many other organisms and poses the threat to food chain contamination (Smith et al., 2016).

Over the past decades, the volume and geography of pesticide usage in the world have significantly changed. With the introduction of modern agricultural technologies, there is a tendency to increase the use of highly effective pesticides with low consumption rates, which can reduce their negative impact on the environment. For example, a new generation of neonicotinoids synthetic analogs of natural nicotine is quickly developed to protect plants from harmful insect species. Unlike nicotine, they have almost no skin-resorptive effects, which enhance their use in fighting against ectoparasites in animals (Bal et al., 2012).

Accordingly, a large number of preparations have been made due to the high insecticidal activity of neonicotinoids. For example, in the United States in 2008, there were about 190 commercial preparations and 600 ones in 2011. Moreover, 45 preparations were registered in Russia in 2012, 35 in Australia in 2011, 30 in the UK in 2010, and 27 in New Zealand in 2010 (Bazaka et al., 2017). 
In 2010, the list of permitted insecticides in Ukraine included 44 preparations based on five active substances (thiamethoxam, imidacloprid, thiacloprid, clothianidin, acetamiprid) containing almost $11 \%$ of the total number of registered insecticides in the world (Bazaka et al., 2018).

A large number of neonicotinoid preparations are available on the market. The spread of these pesticides requires a deep study of their toxic effect on the organism of animals, including poultry. Neonicotinoids have a number of advantages, compared to insecticides of other groups. However, the stability of active substances, acetamiprid, and thiamethoxam, contributes to the long-term migration of residual amounts of the preparations in the environment and the food chain (soil-plant-animal-human) contamination (Bal et al., 2013; Bazaka et al., 2018).

Due to the widespread use of neonicotinoids in agricultural production, veterinary medicine, and general sanitary practice, their negative impact on the animals cannot be ignored. In case of violations of the Standard operative procedures for the use of these substances, the poisoning of animals and people is quite possible (Felsot, 2001; Yermalova et al., 2004).

There are few scientific publications on the toxicity of neonicotinoid preparations for laboratory and productive animals. Only a few articles showed concerns about the effects that occur in acute poisoning (Boyko and Gonohova, 2012). Therefore, it is of utmost importance to study the chronic poisoning of animals with acetamiprid (active substance of Mospilan RP) and thiamethoxam (active substance of Actara $25 \mathrm{WG}$ ).

\section{MATERIALS AND METHODS}

\section{Ethical approval}

Experimental studies were performed on white non-linear mice in accordance with the guidelines of "Toxicological control of new animal protection products" (Lavryshyn et al., 2016), as well as existing documents regulating the organization of work using experimental animals and in compliance with the principles of the European Convention (Strasbourg, 1986) and Article 26 of Law on Ukraine No. 5456-VI of 16.10.2012 "On the protection of animals from cruelty". Provision of the commission on bioethics of the National University of Life and Environmental Sciences of Ukraine (the order №544) was also obtained.

Studies to determine the chronic toxicity of Mospilan RP and Actara 25 WG were performed on non-linear white male mice, aged 2.5 to three months old, weighing 18-20 g. The animals were kept in the vivarium of the faculty of veterinary medicine of the National University of Life and Environmental Sciences of Ukraine. Feeding was carried out according to the diets and norms that are recommended for laboratory animals of this species (Zapadnyuk et al., 1983). While determining the chronic toxicity of Mospilan RP and Actara 25 WG, the mice became adapted to the laboratory conditions for seven days before the initiation of the experiment. During this period, the mice were closely monitored for their clinical condition. Mice were active and mobile, and they consumed food and water well. They had a neat appearance, hair was smooth, clean, well-fitting to the skin. Visible mucous membranes were pink. There were no pathological changes on the skin or injuries. No signs of dysfunction of the respiratory, cardiovascular, and digestive systems were observed. The behavioral responses were characteristic of animals of this species.

Experimental mice were divided into three groups based on the principle of analogs, with seven animals in each group. The dose of the drugs was calculated in mg of the Active Substance (AS) per one kg of body weight. In animals of the experimental group M, chronic poisoning with Mospilan RP was reproduced by daily drinking of an aqueous solution of the drug at a dose of $1 / 10$ Median Lethal Dose $\left(\operatorname{LD}_{50}\right)-65 \mathrm{mg} / \mathrm{kg}$ of body weight. In animals of the experimental group A, chronic poisoning with Actara $25 \mathrm{WG}$ was reproduced by drinking a watering suspension of the drug at a dose of $1 / 10 \mathrm{LD}_{50}(360 \mathrm{mg} / \mathrm{kg}$ of body weight $)$.

The volume of liquid forms for both drugs was $0.4 \mathrm{ml}$. The animals of group III $(n=7)$ served as the control group, and received the same amount of distilled water. The duration of the experiment was 30 days. During the experiment, the animals were monitored, and changes in their clinical condition were constantly noted. The appearance, their reaction to stimuli, changes in body position, behavior, food and water intake, intensity and nature of the motor activity, condition of the skin and mucous membranes were taken into account, and the time of the intoxication development was recorded. At the end of the experiment, when the chronic toxicity was recognized, the mice were euthanized by bloodletting after light chloroform anesthesia. The blood from the heart was taken from all three groups of animals for morphological and biochemical studies of the toxic effects of the Mospilan RP and Actara 25 RG.

\section{Laboratory studies}

The blood for morphological studies was previously stabilized with heparin. The investigated morphological factors were hemoglobin content (HGB), hematocrit (HCT), number of erythrocytes (RBC), platelets (PLT), and leukocytes (WBC) and their forms. Hematological parameters were measured using a specialized veterinary automatic hematology analyzer Micros ABX Vet (Horiba Diagnostics, France). In the plasma, the total protein, albumin, globulin, urea, and creatinine contents, activity of alanineaminotransferase (AlAT), aspartateaminotransferase (AsAT), and 
gamma-glutamyl transpeptidase (GGTP) were studied. Biochemical parameters were examined with the use of a semiautomatic photo electro colorimetric biochemical analyzer Stat-Fax (Awareness Technology, USA) with reagents kits from the HUMAN Company (Germany). The changes in the mass coefficients of the liver, spleen, lungs, kidneys, and heart were determined at the end of the experiment (Gerunova et al., 2012). The results of clinical and biochemical studies were presented in accordance with the International System of Units (SI) recommended for use in clinical laboratory practice (Giknis and Clifford, 2008).

\section{Statistical analysis}

Statistical analyses were carried out using the Microsoft Office Excel program (Shelamova et al., 2010). The reliability of differences among indicators was evaluated using the Student's t-test.

\section{RESULTS AND DISCUSSION}

Considering the available literature, it can be inferred that acetamiprid and thiamethoxam are low-toxic substances (Bal et al., 2012). Half of the $\mathrm{LD}_{50}$ of acetamiprid for white rats is $213 \mathrm{mg} / \mathrm{kg}$ of body weight, and it is $98 \mathrm{mg} / \mathrm{kg}$ of body weight for poultry. Half of the $\mathrm{LD}_{50}$ of thiamethoxam for white rats is $1563 \mathrm{mg} / \mathrm{kg}$ of body weight, and it is $576 \mathrm{mg} / \mathrm{kg}$ of body weight for poultry (Gerunova et al., 2003).

During the entire observation period, there was no significant difference between the experimental groups and the control group of animals in terms of behavioral responses as well as feed and water consumption. The animals were active and mobile, and their coordination was not impaired. Clinical signs of poisoning and death of animals were not observed. This was indicative of the fact that the used dose of studied preparations was not sufficient to cause clinical changes. However, it should be noted that the animals of both experimental groups were more aggressive, and often attacked each other, compared to the control group. The HCT, RBC, and HGB in the blood of animals of experimental groups did not undergo significant changes when comparing with the indicators of the control group (Table1). At the same time, the number of WBC and platelets in the blood reliably increased in white mice of both treated groups.

It should be noted that by microscopic evaluation of the blood smears of the animals in both experimental groups, anisocytosis and microcytosis of WBC were noted. The found leukocytosis we are inclined to explain as a consequence of the development of inflammatory phenomena in the digestive canal after the enteral introduction of drugs (Table 1). More pronounced changes were noted in mice undergoing Mospilan RP treatment, and this indicated that its degree of toxicity was more pronounced than in Actara 25 WG.

Table 1. Blood counts in white mice treated with Mospilan RP and Actara25 WG, M \pm m* $(n=7)$

\begin{tabular}{lccc}
\hline Indicator & \multicolumn{3}{c}{ Group of animals } \\
\cline { 2 - 4 } & Control & Group M & Group A \\
\hline Hematocrit (\%) & $0.34 \pm 0.03$ & $0.33 \pm 0.01$ & $0.37 \pm 0.02$ \\
Erythrocytes (T/L) & $4.43 \pm 0.33$ & $4.37 \pm 0.15$ & $4.68 \pm 0.24$ \\
Hemoglobin (g/L) & $112.70 \pm 9.44$ & $110.97 \pm 4.60$ & $122.43 \pm 7.41$ \\
Leukocytes (G/L) & $7.44 \pm 0.38$ & $8.70 \pm 0.27 * *$ & $8.49 \pm 0.28^{* *}$ \\
Platelets(G/L) & $274.60 \pm 7.31$ & $306.04 \pm 4.90^{* *}$ & $308.34 \pm 8.05^{* *}$
\end{tabular}

*Data are presented as Mean \pm Standard Error of Mean, ${ }^{* *} \mathrm{p} \leq 0.05$; Group M: Mice treated with Mospilan RP, Group A: Mice treated with Actara 25 WG.

Due to the impacts of Mospilan RP and Actara 25 WGT, thrombocytosis in the blood of the experimental mice was considered to be the result of the isolation of immunomodulatory cytokines, which secondarily stimulated the production of platelets. For example, interleukin-6 is known as an anti-inflammatory cytokine, and also stimulates polyploidization of megakaryocytes and platelet formation (Heinrich et al., 1990; van Gool et al., 1990). An analysis of a blood leukogram of the mice suffering from chronic poisoning caused by Mospilan RP showed that leukocytosis had a neutrophilic character with a shift of the neutrophil nucleus to the right leading to an increased number of segmentnuclear neutrophils to 1.5 times (Figure 1).

The data indicated the depletion of hematopoietic organs after 30 daily administration of Mospilan RP to white mice at a dose of $1 / 10$ of $\mathrm{LD}_{50}$. Along with neutrophilia, a decrease in lymphocyte count showed that their number in the blood was almost $10 \%$ lower than in the control group $(\mathrm{p} \leq 0.05)$. No significant deviations were observed in the leukogram of white mice undergoing Actara $25 \mathrm{WG}$ treatment at a dose of $1 / 10$ of $\mathrm{LD}_{50}$, but there was a tendency to neutrophilia with lymphocytopenia, as with Mospilan RP. The difference in the degree of manifestation of the influence of Mospilan RP and Actara $25 \mathrm{WG}$ on the blood system and leukogram indicators was probably related to the degree of toxicity of each drug. Taking into account these parameters, the Mospilan RP indicated higher toxicity, compared to Actara 25 WG. To establish the functional state of organs and systems under toxic load, the determination of 
biochemical parameters in the animals' blood plasma played an important role (Table 2). Chronic poisoning of white mice with Mospilan RP was accompanied by an increase in the total protein content of blood plasma by $18.9 \%$, comparing to the control group, while in mice poisoned with Actara $25 \mathrm{WG}$ only a tendency to total protein increase was observed.

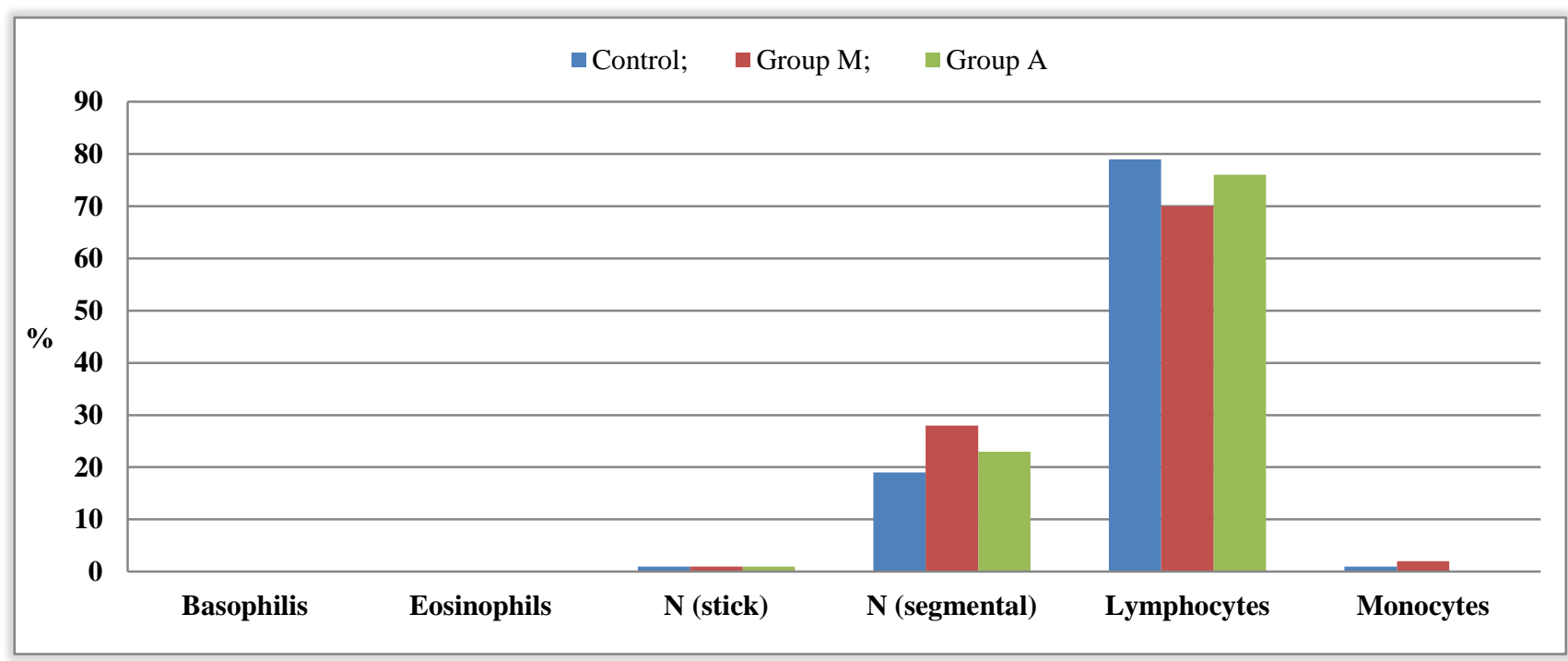

Figure 1. Leukogram of white mice treated with Mospilan RP and Actara $25 \mathrm{WG}(\mathrm{n}=7)$. Group M: Mice treated with Mospilan RP ( $65 \mathrm{mg} / \mathrm{kg}$ of body weight), Group A: Mice treated with Actara $25 \mathrm{WG}$ (360 mg/kg of body weight)

Table 2. Biochemical parameters of blood plasma in white mice undergoing Mospilan RP and Actara 25 WG chronic poisoning, $M \pm m^{*}(n=7)$

\begin{tabular}{lccc}
\hline \multirow{2}{*}{ Indicators } & \multicolumn{3}{c}{ Group of animals } \\
\cline { 2 - 4 } & Control & Group M & Group A \\
\hline Total protein $(\mathrm{g} / \mathrm{l})$ & $50.61 \pm 1.72$ & $60.19 \pm 2.26^{* *}$ & $55.16 \pm 1.75$ \\
Albumins $(\mathrm{g} / \mathrm{l})$ & $24.36 \pm 0.73$ & $26.97 \pm 1.27$ & $21.64 \pm 1.43$ \\
Globulins $(\mathrm{g} / \mathrm{l})$ & $26.25 \pm 1.95$ & $33.22 \pm 2.69^{* *}$ & $33.52 \pm 1.71^{* *}$ \\
Urea $(\mathrm{mmol} / \mathrm{l})$ & $6.03 \pm 0.22$ & $3.41 \pm 0.16^{* *}$ & $4.13 \pm 0.18^{* *}$ \\
Creatinine (mcmol/l) & $59.20 \pm 2.13$ & $55.91 \pm 1.41$ & $54.29 \pm 1.53^{* *}$ \\
\hline
\end{tabular}

Notes: *data are presented as Mean \pm Standard Error of Mean, $* * \mathrm{p} \leq 0.05$; Group M: Mice treated with Mospilan RP, Group A: Mice treated with Actara 25 WG.

The content of albumins in blood plasma remained unchanged although it was slightly higher in animals that were given Mospilan RP. Thus, the increase in the total protein content was associated with an increase in the content of globulins by almost $30.0 \%$ in the blood plasma of animals of both experimental groups. This may due to "irritation" of the phagocytic mononuclear system that originated from the toxic liver damage.

Synthesizing liver function is evaluated by the content of urea in the blood plasma because the urea is formed in the liver. There was a $43.6 \%$ decrease in the urea content in the blood plasma of white mice undergoing chronic Mospilan RP poisoning, and $31.5 \%$ for Actara $25 \mathrm{WG}$ poisoning $(\mathrm{p} \leq 0.05)$. This result indicated an infringement of the ureaforming function of the liver.

Urea is the final product of protein metabolism, the synthesis of which neutralizes ammonia. It is formed mainly in the ornithine cycle in the liver and partially in the kidneys. The energy required for urea synthesis is provided by the Krebs cycle. The concentration of urea in the blood plasma depends on the intensity of its synthesis and excretion. Therefore, the determination of its content is an important diagnostic test of both, the liver function, where it is synthesized, and the kidneys, through which it is excreted (Heinrich et al., 1990). A decrease in urea content in the blood plasma of both experimental groups of mice indicated a severe course of liver pathology. There was also an $8.3 \%$ decrease in creatinine content in the blood plasma of white mice that were given Actara $25 \mathrm{WG}$, comparing to the control animals $(\mathrm{p} \leq 0.05)$. As soon as Actara $25 \mathrm{WG}$ showed less toxic impacts compared to Mospilan RP, the changes in the total protein and urea content in the blood plasma of white mice from chronic poisoning were less pronounced in group A than in animals that were given Mospilan RP.

Along with a decrease in urea content in the blood plasma, there was also a tendency for the decreased liver mass coefficient in mice of the experimental group $\mathrm{M}$, compared with the indicator in the control group. At the same time, a significant decrease in the spleen mass coefficient in this group indicated the hematopoietic function suppression and the 
immunotropic effect of Mospilan RP. These data supported the results of morphological and biochemical studies of mice in experimental group M. The mice that were chronically poisoned with Actara $25 \mathrm{WG}$ revealed no changes in the mass coefficients of internal organs (Table 3).

Table 3. The mass coefficients of internal organs of white mice undergoing Mospilan RP and Actara 25 WG chronic poisoning, $\mathrm{M} \pm \mathrm{m} *(\mathrm{n}=7)$

\begin{tabular}{lccc}
\hline \multirow{2}{*}{ Indicators } & \multicolumn{3}{c}{ Group of animals } \\
\cline { 2 - 4 } & Control & Group M & Group A \\
\hline Liver & $6.19 \pm 0.48$ & $5.60 \pm 0.22$ & $6.28 \pm 0.35$ \\
Spleen & $0.80 \pm 0.08$ & $0.52 \pm 0.08^{* *}$ & $0.82 \pm 0.12$ \\
Lungs & $0.69 \pm 0.03$ & $0.63 \pm 0.02$ & $0.65 \pm 0.03$ \\
Kidneys & $1.66 \pm 0.13$ & $1.60 \pm 0.11$ & $1.69 \pm 0.10$ \\
Heart & $0.53 \pm 0.03$ & $0.55 \pm 0.04$ & $0.56 \pm 0.02$ \\
\hline
\end{tabular}

Notes:*data are presented as Mean \pm Standard Error of Mean, ${ }^{* *} \mathrm{p} \leq 0.05$; Group M: Mice treated with Mospilan RP; Group A: Mice treated with Actara 25 WG.

Aminotransferases (AlAT, AsAT) are localized in most organs and systems. They transfer amino groups from aspartic acid and alanine in alpha-ketoglutarate acid. Both enzymes are allocated in the cytoplasm of cells (AsAT also in mitochondria), and their activity in blood plasma increase with minor tissue damage (van Gool et al., 1990). The study of AsAT and AlAT activity in blood plasma is mostly used for the diagnosis of liver diseases. Their activity increases in several conditions, including acute hepatitis and other inflammatory processes. A moderate increase is observed in mechanical jaundice and cirrhosis of the liver (van Gool et al., 1990; Moser et al., 2015). The presence of hepatotoxic action of Mospilan RP is confirmed by changes in the activity of aminotransferases. In the present study, the activity of AlAT increased by $23.0 \%(\mathrm{p} \leq 0.05)$. At the same time, there were no changes in the activity of AlAT in the blood plasma of mice undergoing chronic poisoning with Actara 25 WG (Figure 2).

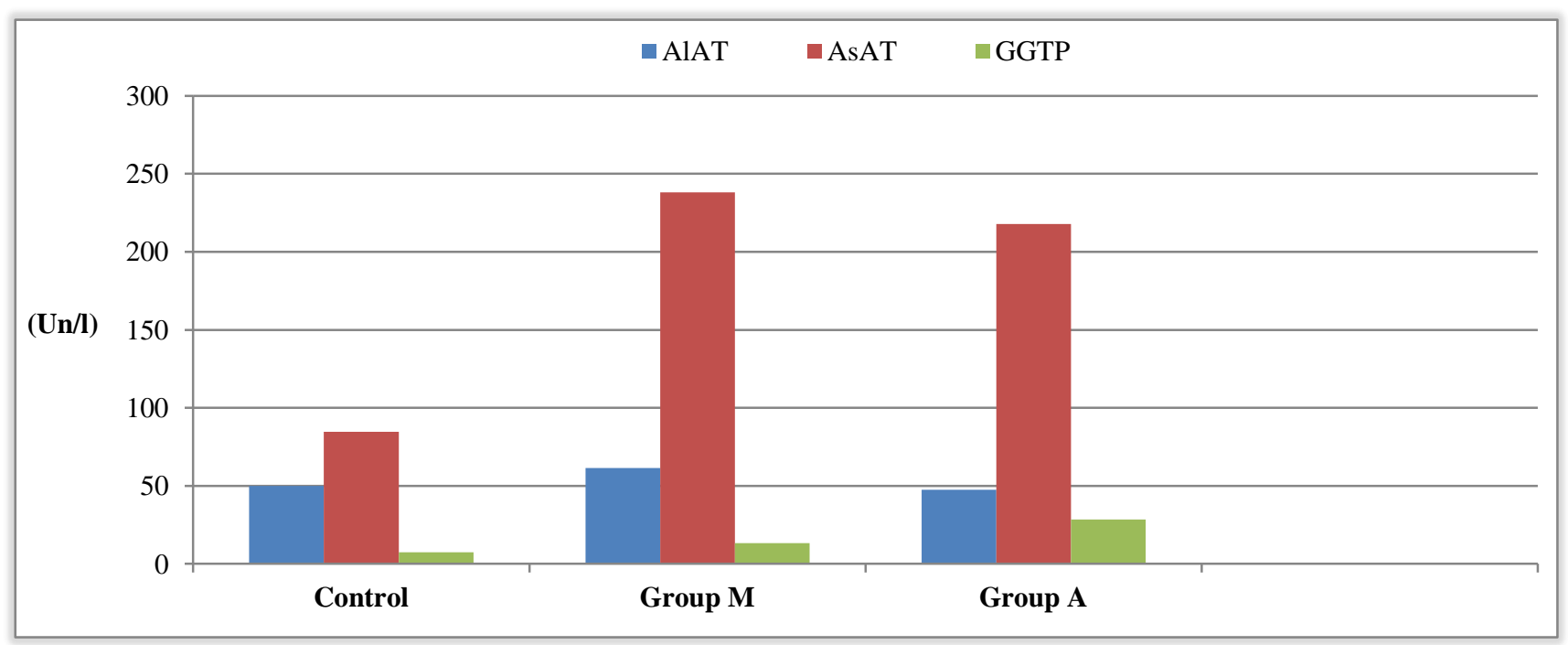

Figure 2. Activity of plasma enzymes in mice undergoing Mospilan RP (group M) and Actara 25 WG (group A) chronic poisoning. Group M: Mice treated with Mospilan RP (65 mg/kg of body weight), Group A: Mice treated with Actara 25 WG (360 $\mathrm{mg} / \mathrm{kg}$ of body weight)

The affinity of neonicotinoids (acetamiprid and thiamethoxam) with nicotine plus their ability to interact with nicotine-sensitive muscle receptors are the reasons for the pronounced effect of both substances on the activity of AsAT in chronic poisoning of white mice (Bal et al., 2013). In the mice treated with Mospilan RP and Actara 25 WG, the activity of this enzyme increased by 2.8 and 2.6 times, respectively $(\mathrm{p} \leq 0.05)$.

Gammaglutamyltranspeptidase catalyzes the transfer of a glutamyl residue and a gamma-glutamylpeptide to an acceptor peptide or an alpha-amino acid. The enzyme is highly active in the kidneys, liver, especially in the cells that form the renal tubules and bile ducts, as well as in the pancreas. An increase in GGTP level is an early and reliable test of inter hepatic bile stasis, damage to hepatocyte membranes near the biliary pole, and to epithelial cells that line the lumen of the bile ducts (Chakroun et al., 2017). In mice undergoing Mospilan RP chronic poisoning, GGTP activity increased by 1.8 times, and a simultaneous increase in AlAT and AsAT activity indicated the manifestation of hepatocytolysis. At the same time, the increase in GGTP activity in mice undergoing Actara $25 \mathrm{WG}$ chronic poisoning by almost four times 
without changes in AlAT activity and with less prominent changes of AsAT activity indicated the development of lesions mainly in the bile ducts.

Other studies claim that neonicotinoids are capable to accumulate in the components of treated plants (Buszewski et al., 2019), are found in human serum and urine (Yamamuro et al., 2014), and has the potential to act as neurotoxic compounds (Christen et al., 2017). We consider that these findings further support the importance of our results and sustain the necessity to continue the research in this avenue.

\section{CONCLUSION}

Daily oral administration of Mospilan RP and Actara $25 \mathrm{WG}$ at $1 / 10$ of the median lethal dose in the experimental mice for 30 days caused the development of thrombocytosis, neutrophilic leukocytosis, lymphocytopenia, hyperproteinemia due to an increase in the content of globulins and liver dysfunction. The liver dysfunction was more expressed in mice undergoing a chronic poisoning by Mospilan RP that was indicated by a more pronounced decrease of urea content and an increase in AsAT and AlAT activity comparing with animals that underwent a chronic poisoning by Actara 25 WG. Consequently, the above results indicated the feasibility of further studies addressing the effects of Mospilan RP and Actara $25 \mathrm{WG}$ on others species of animals while paying attention to the changes of potentially more susceptible indexes, such as genetic apparatus or reproductive function.

\section{DECLARATIONS}

\section{Acknowledgments}

This work was supported by the National University of Life and Environmental Sciences of Ukraine.

\section{Competing interests}

The authors have declared that no competing interest exists.

\section{Authors' contribution}

VD, VS, and NK planned and conducted the research and collected data. IL, VH, and VK elaborated the study design, performed the statistical analysis, and wrote the manuscript. All authors have read and approved the final manuscript.

\section{Ethical considerations}

Ethical issues (including plagiarism, consent to publish, misconduct, data fabrication and/or falsification, double publication and/or submission, and redundancy) have been checked by the authors.

\section{REFERENCES}

Bal R, Türk G, Tuzcu M, and Yilmaz O (2012). Assessment of imidacloprid toxicity on reproductive organ system of adult male rats. Journal of Environmental Science and Health, Part B Pesticides, Food Contaminants, and Agricultural Wastes, 47(5): 434-444. DOI: https://www.doi.org/10.1080/03601234.2012.663311

Bal R, Türk G, Tuzcu M, Yilmaz O, Kuloglu T, Baydas C, Naziroglu M, Vener Z, Ttem E, and Tuxcu Z (2013). Effects of the neonicotinoid insecticide, clothianidin, on the reproductive organ system in adult male rats. Drug and Chemical Toxicology, 36(4): 421-429. DOI: https://www.doi.org/10.3109/01480545.2013.776575

Bazaka GY, Dukhnitskyi VB, and Ishchenko VD (2017). Comparative study of mospilana and akhtar chronic toxicity for white mice. Ukrainian Journal of Veterinary Sciences, 265: 8-16. Available at: http://journals.nubip.edu.ua/index.php/Veterenarna/article/view/10606

Bazaka G, Borysevich B, and Dukhnitskiy V (2018). Pathoanatomical changes in the laying hens' organism at mospilan RP and aktara 25 WG chronic poisoning. Ukrainian Journal of Veterinary Sciences, 285: 21-26. Available http://journals.nubip.edu.ua/index.php/Veterenarna/article/view/12497

Boyko TV, and Gonohova MN (2012). Kliniko-morfologicheskie proyavleniya ostrogo otravleniya ptits neonikotinoidami. Vesnik veterinarii, 63(4): 104-106. Available at: http://www.stgau.ru/science/conference/conference 21.11.12/doklad/10.pdf

Buszewski B, Bukowska M, Ligor M, and Staneczko-Baranowska I (2019). A holistic study of neonicotinoids neuroactive insecticides-properties, applications, occurrence, and analysis. Environmental Science and Pollution Research, 26(34): 34723-34740. DOI: https://www.doi.org/10.1007/s11356-019-06114-w

Chakroun S, Grissa I, Ezzi L, Ammar O, Neffati F, Kerkeni E, Najjar M, Haouas Z, and Cheikh H (2017). Imidacloprid enhances liver damage in Wistar rats: Biochemical, oxidative damage and histological assessment. Journal of Coastal Life Medicine, 5(12): 540-546. DOI: https://www.doi.org/10.12980/jclm.5.2017J7-149

Christen V, Rusconi M, Crettaz P, and Fent K (2017). Developmental neurotoxicity of different pesticides in PC-12 cells in vitro. Toxicology and Applied Pharmacology, 15(325): 25-36. DOI: https://www.doi.org/10.1016/j.taap.2017.03.027

Felsot A (2001). Admiring risk reduction. Does imidacloprid have what it takes? Agrichemical and Environmental News, 186: 1-12. Available at: http://www.aenews.wsu.edu/Oct01AENews/Oct01AENews.htm\#Admiring

Gerunova L, Gerunov V, Boyko T, and Gonokhova M (2012). Patomorfologicheskie izmeneniya i dinamika nakopleniya ostatkov imidakloprida v pecheni kryis pri eksperimentalnom otravlenii. Agrarnyiy vesnik Urala, 5(97): 32-34. Available at: http://www.mavu.narod.ru/PDFkee/AVU_05_2012.pdf 
Gerunova LK, Okolelov VI, and Boiko TV (2003). Hematotoxicological action of pesticides on hematothermal animals. Agricultural Biology, 4: 75 78. Available at http://www.agrobiology.ru/4-2003.html

Giknis MLA, and Clifford CB (2008). Clinical laboratory parameters for Crl: WI (Han) rats. Charles River Laboratories, pp. 1-14. Available at: https://www.criver.com/sites/default/files/resources/rm_rm_r_Wistar_Han_clin_lab_parameters_08.pdf

Heinrich PC, Castell JV, and Andus T (1990). Interleukin-6 and the acute phase response. Biochemical Journal, 265(3): 621-636. DOI: https://www.doi.org/10.1042/bj2650621

Kovalenko VG, Tyurina NM, and Kazadaeva SV (2010). Pesticides in the system of integrated control over the development and spread of pests and diseases of crops. Agricultural Chemistry, 4: 43-52. Available at: https://naukabooks.ru/zhurnali/katalog/agrohimija/

Lavryshyn YY, Varkholyak IS, Martyschuk TV, Guta ZA, and Ivankiv LB (2016). The biological significance of the antioxidant defense system of animals animals' body. Scientific Messenger of LNU of Veterinary Medicine and Biotechnologies. Veterinary Sciences, 2(66): 100-111. DOI: https://www.doi.org/10.15421/nvlvet6622

Moser VC, Stewart N, Freeborn DL, Crooks J, MacMillan DK, Hedge JM, and Herr DW (2015). Assessment of serum biomarkers in rats after exposure to pesticides of different chemical classes. Toxicology and Applied Pharmacology, 282(2): 161-174. DOI: https://www.doi.org/10.1016/j.taap.2014.11.01620.

Shelamova MA, Insarova NI, and Leshchenko VG (2010). Statistical analysis of biomedical data using the Excel program. BSMU Repository, p. 96. Available at: http://rep.bsmu.by/handle/BSMU/3865

Smith HA, Nagle CA, MacVean CA, and McKenzie CL (2016). Susceptibility of bemisia tabaci MEAM1 (Hemiptera: Aleyrodidae) to imidacloprid, thiamethoxam, dinotefuran and flupyradifurone in South Florida. Insects, 7(4): Article number 57. DOI: https://www.doi.org/10.3390/insects7040057

Strasbourg (1986). European convention for the protection of vertebrate animals used for experimental and other scientific purposes. Council of Europe. ETS - No. 123. Available at: https://www.coe.int/en/web/conventions/full-list///conventions/treaty/123

van Gool J, van Vugt H, Helle M, and Aarden LA (1990). The relation among stress, adrenalin, interleukin-6 and acute phase proteins in the rat. Clinical Immunology and Immunopathology, 57(2): 200-210. DOI: https://www.doi.org/10.1016/0090-1229(90)90034-N

Wood S, Kozii I, Medici de Mattos I, de Carvalho Macedo Silva R, Klein C, Dvylyuk I, Moshynskyy I, Tasha E, and Simko E (2019). Chronic highdose neonicotinoid exposure decreases overwinter survival of Apis mellifera L. Insects, 11(1): Article number 30. Available at: https://www.mdpi.com/2075-4450/11/1/30

Wood S, Kozii I, Koziy R, Epp T, and Simko E (2018). Comparative chronic toxicity of three neonicotinoids on New Zealand packaged honey bees. PLoS One, 13(1): e0190517. DOI: https://www.doi.org/10.1371/journal.pone.0190517

Yamamuro T, Ohta H, Aoyama M, and Watanabe D (2014). Simultaneous determination of neonicotinoid insecticides in human serum and urine using diatomaceous earth-assisted extraction and liquid chromatography-tandem mass spectrometry. Journal of Chromatography B Analytical Technologies in the Biomedical and Life Sciences, 15(969): 85-94. DOI: https://www.doi.org/10.1016/j.jchromb.2014.06.008

Yermalova L, Prodanchuk N, Zhminko P, and Lepeshkin I (2004). Comparative toxicological assessment of new neonicotinoid insecticides. Modern problems of toxicology, 42: 4-7. Available at: http://medved.kiev.ua/arhiv_mg/st_2004/042_1en.htm

Zapadnyuk IP, Zapadnyuk VI, Zechariah EA, and Zapadnyuk BV (1983). Laboratory animals: Breeding, maintenance, use in the experiment. Kiev, Vischa shkola, p. 383. Available at: https://www.twirpx.com/file/453758/ 